\title{
Hubungan Kecerdasan Emosional dan Motivasi Mengajar dengan Kinerja Guru IPS SMP di Provinsi Maluku Utara
}

\author{
Irwan Abdullah \\ Pendidikan Geografi, STKIP Kie Raha Ternate, Indonesia \\ irwanabdullah833@gmail.com
}

\begin{abstract}
Abstrak
Tujuan penelitian ini adalah untuk: (1) mengetahui klasifikasi tinggi atau rendahnya tingkat kecerdasan emosional (Emotional Quotien, EQ), motivasi mengajar dan kinerja guru, (2) mengetahui hubungan antara kecerdasan emosional dengan kinerja guru guru, (3) mengetahui hubungan antara motivasi mengajar dengan kinerja guru guru, dan (4) mengetahui hubungan antara EQ dan motivasi mengajar dengan kinerja guru. Penelitian ini dengan metode ex-postfacto.Sampel dalam penelitian ini adalah guru IPS SMP di Provinsi Maluku Utara tahun 2019/2020. Hasil penelitian memberikan gambaran bahwa: (1) EQ, motivasi mengajar dan kinerja guru, termasuk dalam kategori tinggi;EQ dan kinerjaguru, termasuk dalam kategori tinggi;motivasi mengajar dengan Kinerja guru, termasuk dalam kategori sedang; (2) terdapat hubungan kuat positif antara EQ dengan kinerjaguru sebesar 0,634; (3) terdapat hubungan kuat positif antara motivasi mengajar dengan kinerja guru sebesar 0,641; dan (4) terdapat hubungan kuat positif antara EQ dan motivasi mengajar dengan kinerja guru sebesar 0,772 .
\end{abstract}

Kata kunci: kecerdasan emosional, kinerja guru, motivasi mengajar.

Dikirim: 07 Januari 2021

Direvisi: 05 Juni 2021

Diterima: 11 Juni 2021

Identitas Artikel:

Abdullah, I. (2021). Hubungan Kecerdasan Emosional dan Motivasi Mengajar deengan Kinerja Guru IPS SMP di Provinsi Maluku Utara. Jurnal Ilmu Pendidikan (JIP) STKIP Kusuma Negara, 13(1), 35-43.

\section{PENDAHULUAN}

Pendidikan seakan menjelma menjadi syarat mutlak sebuah kesuksesan. Pada kenyataannya, terkadang guru yang memiliki jenjang pendidikan yang tinggi kurang berhasil dalam membelajarkan peserta didik, intelektual yang terbilang tinggi pun, tidak juga menjanjikan hasil belajar yang baik untuk peserta didik. Karena Intelligence Quotient (IQ) bukan satu-satunya penentu keberhasilan dalam belajar (Nasryah \& Rahman, 2019). Dari sini EQ berperan penting (Kurniasari, 2016). Mengapa demikian, karena emosi tidak hanya mengandung makna marah atau tidak suka terhadap sesuatu, namun emosi memiliki banyak macam seperti kesedihan, amarah, rasa takut, kenikmatan, cinta, terkejut, jengkel, dan malu (Ghassani \& Saifudin, 2020; Fitri \& Adelya, 2017). Semuanya dapat mempengaruhi diri individu dalam melakoni profesi sebagi seorang guru (Tridhonanto, 2009).

Keberhasilan pendidikan banyak ditentukan oleh beberapa faktor diantaranya adalah faktor internal dan eksternal. Faktor internal datang dari diri siswa itu sendiri. Termasuk faktor internal adalah fisiologis dan faktor psikologis. Faktor fisiologis meliputi kondisi fisiologis secara umum termasuk panca indera. Sedangkan yang termasuk faktor psikologis adalah minat, kecerdasan, bakat. 
motivasi dan sikap kognitif. Faktor eksternal berasal dari luar individu seperti lingkungan sosial yang mencakup tingkat cara mendidik anak, kurikulum, sarana prasarana, sistem pengajaran, faktor guru dan lain-lain (Yulika, 2019).

Kinerja guru IPS SMP di Provinsi Maluku utara masih jauh dariapa yang diharapkan, banyak guru yang belum dapat membuat perencanaan pembelajaran dengan baik, perencanaan pembelajaran meliputi rumusan tentang apa yang akan dilakukan dalam memfasilitasi kegiatan belajar peserta didik, apalagi pembelajaran IPS sangat terkait dengan alam sekitar (Shofuroh, Arifin \& Fahmi, 2018). Perencanaan mendorong terselenggaranya proses pembelajaran yang baik, seperti kebutuhan peserta didik, standar kompetensi dan kompetensi dasar, tujuan pembelajaran, strategi yang relevan untuk mewujudkan kompetensi dasar dan mencapai tujuan yang telah ditetapkan. Secara keseluruhan hal ini membutuhkan kemampuan agar tetap tenang dan terkendali di bawah himpitan stress dari luar dan dalam diri, sebab kualitas pekerjaan yang menjadi tanggung jawab individu lebih membutuhkan kualitas kemampuan interpersonal (Goleman, 2009; 2002)

Penelitian ini bertujuan untuk mengetahui: (1) klasifikasi tinggi atau rendahnya tingkat EQ, motivasi mengajar, dan kinerja guru, (2) hubunganantara EQ dengan kinerja guru, (3) hubungan antara motivasi mengajar dengan Kinerja guru,dan (4) hubungan antara EQ dan motivasi mengajar dengan kinerja guru.

\section{METODE PENELITIAN}

Pendekatan yang digunakan peneliti adalah pendekatan kuantitatif karena data yang dikumpulkan berbentuk angka-angka yang kemudian dianalisis dengan menggunakan rumus-rumus statistika. Penelitian ini menggunakan metode expostfacto. Penelitian ex-post facto adalah penelitian yang bertujuan menemukan penyebab yang memungkinkan perubahan fenomena, gejala, atau perilaku yang disebabkan oleh suatu perilaku dan peristiwa yang menyebabkan perubahan pada variabel bebas yang secara keseluruhan sudah terjadi (Sugiono, 2013).

\section{Populasi dan Sampel}

Populasi dalam penelitian ini adalah seluruh guru IPS SMP di Provinsi Maluku Utara yang berjumlah 1026 orang. Sedangkan sampelnya adalah bagian dari jumlah tersebut yang pengambilannya dilakukan dengan teknik multistage random sampling. Adapun penentuan ukuran sampel dengan menggunakan rumus Slovin (Sugiyono, 2013). Ukuran sampel yang dihitung dengan rumus tersebutdarikeseluruhan jumlah populasi 1026 dan tingkat kesalahan $10 \%$ sehingga diperoleh 91,11. Jadi ukuran sampel yang diperoleh adalah sebesar 92 guru, namun dalam penelitian ini peneliti menggunakan sampel sebanyak 115 yang berada di atas sampel minimal.

\section{Instrumen Penelitian}

Alat ukur dalam penelitian biasanya dinamakan instrumen penelitian, yaitu alat yang digunakan dalam mengumpulkan data.Instrumen yang digunakan dalam penelitian ini berupa skala psikologi. Penetapan skor instrumen menggunakan empat pilihanrespon. Responden hanyamemberikan tanda $(\sqrt{ })$ pada jawaban yang tersedia yang sesuai dengan keadaandirinya. Selalu, sering, kadang-kadang dantidak pernah merupakan pilihan respon yang tersedia yang ditandai oleh siswa. 


\section{Teknik Pengumpulan Data}

Teknik pengumpulan data dalam penelitian inidikumpulkan melalui teknik kuisioner.Teknik kuisioner merupakan alat yang digunakan dalam mengumpulkan informasi yang berkaitan dengan EQ, motivasi mengajar dan kinerja guru IPS SMP (Tiro, 2002).

\section{Teknik Analisis data}

Data hasil penelitian dianalisis dengan statistik deskriptif dan inferensial. Statistik deskriptif yang dihitung adalah rata-rata (mean) dan standar deviasi. Kemudian, sebelum pengujian hipotesis secara inferensial maka terlebih dahulu dilakukan uji prasyarat analisis. Pada analisis data prasyarat menurut Tiro (2002) yaitu: uji normalitas dengan uji Kolmonogorof-Smirnov dengan bantuan program SPSS 20, uji homogenitas dengan menggunakan Levene's test, dan uji linearitas. Setelah data dianalisis dengan uji prasyarat, maka dilanjutkan dengan uji hipotesis.

Pengujian hipoteisis adalah dengan analisis regresi sederhana, analisis korelasi Product Moment, analisis regresi ganda dan analisis korelasi ganda. Untuk mengukur derajat keeratan hubungan, memprediksi besarnya arah hubungan antar variabel, serta meramalkan besarnya variabel tak bebas jika dinilai variabel bebas diketahui digunakan analisis regresi sederhana. Kemudian untuk mencari hubungan dan menguji hipotesis hubungan satu variabel bebas dan variabel tak bebas digunakan analisis korelasi product moment. Kemudian, untuk mengetahui arah dan kuatnya hubungan antara EQ dan motivasi mengajar terhadap kinerja guru digunakan regresi ganda. Pengujian hipotesis dengan analisis regresi ganda dengan merujuk pada sumber Sugiyono (2013).

\section{HASIL PENELITIAN}

\section{Hasil Analisis Deskriptif EQ Guru}

Hasil analisis deskriptif menunjukan bahwa skor rata-rata (mean) pada variabel EQ guru sebesar 199,40dan standar deviasinya sebesar 16,08. Skor EQ guru dirangkum dalam Tabel distribusi frekuensi, yaitu Tabel 2.

Tabel 2. Distribusi Frekuensi Skor EQ Guru

\begin{tabular}{cccc}
\hline Skor EQ & Titik Tengah & Frekuensi & Kategori \\
\hline $52-94$ & 73 & 0 & Sangat Rendah \\
$95-137$ & 116 & 0 & Rendah \\
$138-180$ & 159 & 19 & Sedang \\
$181-223$ & 202 & 96 & Tinggi \\
$224-267$ & 245,5 & 0 & Sangat Tinggi \\
\hline
\end{tabular}

\section{Hasil Analisis Deskriptif Motivasi Mengajar Guru}

Hasil analisis deskriptif menunjukkan bahwa skor rata-rata (mean) responden pada variabel motivasi mengajar guru sebesar 153,47 standar deviasi sebesar 10,52 . 
Tabel 3. Distribusi Frekuensi Skor Motivasi Mengajar Guru

\begin{tabular}{clll}
\hline Skor Motivasi Mengajar & Titik Tengah & Frekuensi & Kategori \\
\hline $53-92$ & 74 & 0 & Sangat Rendah \\
$95-150$ & 112,5 & 0 & Rendah \\
$136-189$ & 160,5 & 20 & Sedang \\
$171-210$ & 190,5 & 202 & Tinggi \\
$211-250$ & 230,5 & 0 & Sangat Tinggi \\
\hline
\end{tabular}

\section{Hasil Analisis Deskriptif Kinerja Guru}

Hasil penelitian menunjukkan bahwa skor rata-rata (mean) responden pada variabel kinerja guru sebesar 190,46 standar deviasi sebesar 14,68.

Tabel 4. distribusi frekuensi Skor Kinerja Guru

\begin{tabular}{cccc}
\hline SkorKinerja Guru & Titik Tengah & Frekuensi & Kategori \\
\hline $51-90$ & 70,5 & 0 & Sangat Rendah \\
$91-130$ & 110,5 & 0 & Rendah \\
$131-170$ & 150,5 & 11 & Sedang \\
$171-210$ & 190,5 & 95 & Tinggi \\
$211-250$ & 230,5 & 9 & Sangat Tinggi \\
\hline
\end{tabular}

\section{Uji Normalitas}

Pengujian normalitas masing-masing variabel dilakukan dengan maksud untuk mengetahui apakah sebaran data dari setiap variabel tidak menyimpang dari ciri yang berdistribusi normal. Pengujian normalitas dilakukan dengan SPSS.20.

Tabel 5. Uji Normalitas

\begin{tabular}{lccc}
\hline & \multicolumn{3}{c}{ Kolmogorov-Smirnov } \\
\cline { 2 - 4 } & Statistik & $d k$ & Sig \\
\hline EQ & 0,83 & 115 & 0,52 \\
Motivasi Mengajar & 0,80 & 115 & 0,66 \\
Kinerja Guru & 080 & 115 & 064 \\
\hline
\end{tabular}

Berdasarkan Tabel 5, hasil pengujian normalitas dengan menggunakan analisis Kolmogorov-Smirnov diperoleh nilai signifikansi untuk variabel EQ guru sebesar 0,52 pada taraf signifikan $\alpha=0,05$. Telihat bahwa 0,52 lebih dari 0,05 sehingga menunjukkan data EQ berasal dari populasi berdistribusi normal. Hasil pengujian normalitas untuk variabel motivasi mengajar diperoleh nilai signifikansi sebesar 0,66 pada taraf signifikansi $\alpha=0,05$. Terlihat bahwa 0,66 lebih dari 0,05 sehingga menunjukkan data motivasi mengajar guruberasal dari populasi berdistribusi normal. Sedangkan hasil pengujian normalitas pada variabel kinerja guru diperoleh nilai signifikansi sebesar 0,64 pada taraf signifikansi $\alpha=0,05$. Terlihat bahwa 0,64 lebih dari0,05 sehingga menunjukkan data kinerja guru berasal dari populasi berdistribusi normal.

\section{Uji Homogenitas}

Uji homogenitas dimaksudkan untuk memperlihatkan bahwa dua atau lebih kelompok data sampel berasal dari populasi yang memiliki varian yang sama. Hasil analisis dirangkum dalam Tabel 6. 
Tabel 6. Uji Homogenitas

\begin{tabular}{llll}
\hline & \multicolumn{3}{c}{ Levene's test } \\
\cline { 2 - 4 } & Statistik & $d k$ & Sig \\
\hline EQ & 0,83 & 115 & 0,52 \\
Motivasi Mengajar & 0,80 & 115 & 0,52 \\
Kinerja Guru & 0,80 & 115 & 064 \\
\hline
\end{tabular}

Berdasarkan Tabel 6, uji homogenitas varian dengan menggunakn Levene's statistic, menunjukan bahwa EQ memiliki nilai signifikansi sebesar 0,112 dan untuk motivasi mengajar diperoleh nilai signifikansi 0,107 . Keduanya memiliki nilai signifikansi lebih dari $\alpha=0,05$, sehingga varian dari dua kelompok data populasi adalah sama.

\section{Uji Multikolinearitas}

Hasil uji multikolinearitas antara variabel EQ dan motivasi mengajar guru IPS diperoleh bahwa nilai tolerance variabel EQdan motivasi mengajar yakni 0,867 lebih besar dari 0,10. Sementara itu, Nilai VIF variabel EQ dan motivasi mengajar yakni 1,154 lebih kecil dari 10,00. Sehingga dapat disimpulkan tidak terjadi Multikolinearitas antara kedua variabel bebas.

\section{Uji Linearitas}

Berdasarkan uji ANOVA untuk data EQ dengan kinerja guru ternyata diperoleh nilai signifikansi sebesar $0,002<\alpha$. Hasil ini menunjukkan kedua variabel tersebut berhubungan secara linear pada taraf signifikansi 5\%. Sedangkanberdasarkan uji ANOVA untuk datamotivasi mengajar dengan kinerja guru IPS ternyata diperoleh nilai signifikansi hitung sebesar $0,000<\alpha$. Hasil ini menunjukkan kedua variabel tersebut berhubungan secara linear pada taraf signifikansi $5 \%$. Berdasarkan uji prasyarat analisis di atas, maka dapat ditentukan bahwa jenis statistik yang digunakan dalam mengolah data ketiga variabel penelitian adalah dengan statistik parametrik.

\section{Analisis Hubungan antara EQ dan Kinerja Guru}

Dari hasil pengolahan data, dengan hipotesis penelitiannya adalah terdapat hubungan positif yang signifikan antara EQ dengan kinerja guru, berikut rangkuman hasil analisis dimuat dalam Tabel 7.

Tabel 7. Hubungan antara EQ dan Kinerja Guru

\begin{tabular}{ccc}
\hline$r$ & $R^{2}$ & Adjusted $R$ Square \\
\hline 0.634 & 0.402 & 0.397 \\
\hline
\end{tabular}

Tabel 6 menunjukkan nilai korelasi $r=0,634$ dapat diinterpretasikan bahwa hubungan antara EQ dengan kinerja guru adalah kuat positif. Arti positif adalah hubungan antara EQ dengan kinerja guru searah. Artinya, semakin bagus EQ guru maka semakin bagus pula kinerja guru nya. Begitu juga sebaliknya semakin rendah EQ guru maka semakin rendah kinerja guru. Sedangkan untuk menyatakan besar kecilnya kontribusi (sumbangan) variabel EQ terhadap kinerja guru atau koefisien determinasinya sama dengan $r^{2} \times 100 \%$ atau $0,634 \times 0,634 \times 100 \%=0,402$ 
Hal ini berarti EQ memberikan kontribusi sebesar 40,2\% terhadap kinerja guru dan sisanya $59,8 \%$ di tentukan oleh faktor-faktor lain yang tidak diselidiki dalam penelitian ini.

\section{Analisis Hubungan antara Motivasi Mengajar dan Kinerja Guru}

Dari hasil pengolahan data, dengan hipotesis penelitiannya adalah terdapat hubungan positif yang signifikan antara motivasi mengajar dengan kinerja guru, berikut rangkuman hasil analisis dimuat dalam Tabel 8 .

Tabel 8. Hubungan Motivasi Mengajar dan Kinerja Guru

\begin{tabular}{ccc}
\hline$r$ & $R^{2}$ & Adjusted $R$ Square \\
\hline 0,641 & 0,411 & 0,406 \\
\hline
\end{tabular}

Tabel 7 menunjukkan bahwa nilai korelasi $(r)=0,641$ Nilai ini dapat diinterpretasikan bahwa hubungan antara motivasi mengajar dengan kinerja guru adalah kuat positif. Arti positif adalah hubungan antara motivasi mengajar dengan kinerja guru searah. Artinya, semakin bagus motivasi mengajar maka semakin bagus pula kinerja guru IPS nya. Begitu juga sebaliknya semakin buruk motivasi mengajar maka semakin rendah kinerja guru IPS. Melalui tabel ini juga nilai koefisien determinasi menunjukkan seberapa bagus model regresi yang dibentuk oleh interaksi antara motivasi mengajar dengan kinerja guru. Nilai koefisien determinasi yang diperoleh adalah 0,411 yang dapat ditafsirkan bahwa motivasi mengajar memiliki pengaruh $41,1 \%$ terhadap kinerja guru.

\section{Hubungan EQ dan Motivasi Mengajar dengan Kinerja Guru}

Dari hasil pengolahan data, dengan hipotesis terdapat hubungan EQ dan motivasi mengajar dengan kinerja guru, berikut rangkuman hasil analisis dimuat dalam Tabel 9.

Tabel 9. Hubungan EQ dan Motivasi Mengajar dengan Kinerja Guru

\begin{tabular}{ccc}
\hline$r$ & $R^{2}$ & Adjusted $R$ Square \\
\hline 0,772 & 0,596 & 0,589 \\
\hline
\end{tabular}

Berdasarkan Tabel 9, bahwa hasil korelasi ( $r$ ) yang secara simultan (bersamasama) antara EQ dan motivasi mengajar dengan kinerja guru diperoleh nilai sebesar 0,772. Dengan demikian kontribusi yang diberikan oleh keceerdasan emosional dan motivasi mengajar terhadap kinerja guru adalah koefisien determinan sebesar (KD) sama dengan 0,596, artinya kinerja gurudipengaruhi oleh EQ dan motivasi mengajar sebesar 59,6 \%.Analisis kemudian dilanjutkan dengan perhitungan ANOVA, yang hasilnya dirangkum pada Tabel 10.

Tabel 10. ANOVA Hubungan kecerdasan Emosioal dan Motivasi Mengajar

\begin{tabular}{lccccc}
\multicolumn{6}{c}{ dengan Kinerja Guru } \\
\hline Model & $d f$ & Mean Square & $F$ & Sig. \\
\hline & Regression & 2 & 19890,000 & 82.519 & 000 \\
1 & Residual & 112 & 241,036 & & \\
Total & 114 & & & \\
\hline
\end{tabular}


Berdasarkan Tabel 10, diperoleh nilai $F_{\text {hitung }}$ sebesar 82,519 dengan nilai probalitas (Sig) 0,000. Karena nilai probalitas ( $\mathrm{Sig}$ ) $0,000<0,05$ maka model persamaan regresi berdasarkan data penelitian adalah signifikan. Jadi model regresi ganda dapat digunakan untuk memprediksi pengaruh secara simultan EQ dan motivasi mengajar dengan kinerja guru. Selanjutnya untuk melihat persamaan regresi ganda dalam memperkirakan kinerja guru yang dipengaruhi oleh EQ dan motivasi mengajar berlandaskan pada tabel koefisien.

Nilai $F_{\text {hitung }}$ sebesar 82,519 dengan taraf signifikansi 0,000 memberikan arti bahwa variabel EQ dan motivasi mengajar berpengaruh terhadap kinerja guru. Koefisien determinasi (KD) sama dengan $r^{2} \times 100 \%$ atau $0,772 \times 0,772 \times 100 \%$, yaitu 0,596 . Artinya, 59,6\% kinerja guru dapat dijelaskan oleh variabel EQ dan motivasi mengajar. Sisanya 40,4\% dijelaskan oleh faktor selain EQ dan motivasi mengajar.

\section{PEMBAHASAN}

Variabel motivasi mengajar guru umumnya berada pada kategori tinggi. Data ini memberikan gambaran bahwa motivasi guru IPS SMP yang ada di Provinsi Maluku Utara sudah memiliki komponen-komponen motivasi mengajar meliputi tanggung jawab dalam menjalankan tugas, kerja keras atas amanah yang telah diberikan untuk mencapai tujuan organisasi/sekolah, serta dorongan untuk terus meningkatkan kinerjanya. guru yang memiliki motivasi tinggi memiliki dorongan untuk membelajarkan peserta didik, terutama motivasi yang ada dalam diri guru itu sendiri, sehingga walaupun guru tersebut berada dalam masalah, usaha untuk bertanggung jawab pada tugasnya tetap terlaksana.

Untuk variabel kinerja guru, umumnya berada pada kategori tinggi. Walaupun demikian masih saja ada guru yang belum baik dalam melakukan kinerjanya, hal ini dipengaruhi faktor-faktor lain seperti masih mengangap tugas guru hanya sekedar mengajar semata, tanpa melihat kesulitan apa yang dialami oleh peserta didik, sehingga perlu diadaknnya perbaikan dalam pembelajaran, motivasi eksternal yang lebih berperan seperti, kurangnya insentif ataupun pujian dari teman sprofesi, sehingga kinerjanya menurun.

Analisis inferensial yang digunakan dalam penelitian ini adalah analisis regresi. Semuanya akan dibahas sebagai berikut. Berdasarkan hasil analisis regresi sederhanadengan menggunakan SPSS 20 dapat disimpulkan terdapat hubungan positif yang signifikan antara EQ guru degan kinerja guru. Dari perhitungan koefisien determinasi (KD) diperoleh kontribusi EQ guru terhadap kinerja guru sebesar 40,2\%. Sedangkan sisanya sebebsar 59,8\% kinerja guru dipengaruhi oleh faktor-faktor lain yang tidak diteliti dalam penelitian ini. hal ini mengindikasikan bahwa variabel EQ memiliki hubungan dengan kinerja guru.

Sebagai tenaga profesional kependidikan guru memiliki motivasi kerja yang berbeda antara guru yang satu dengan lainnya. Hal ini kelak akan berakibat adanya perbedaan kinerja guru dalam meningkatkan mutu pendidikan Herzberg (dalam Kristianto, 2012) menyatakan bahwa "motivasi kerja bukanlah dimensi tunggal, tetapi tersusun dalam dua faktor, yaitu: faktor motivator (satisfier) dan faktor hygiene“. Walaupun demikian motivasi mengajar memiliki hubungan yang signifikan dengan kinerja guru hal ini sejalan dengan penelitian (Suparno, 2005) 
bahwa motivasi kerja memiliki hubungan yang signifikan dengan kinerja guru, yang terlihat dari nilai $r$ sama dengan 0,375 .

Berdasarkan hasil penelitian bahwa EQ dan motivasi mengajar memiliki hubungan yang signifikan dengan kinerja guru. Guru mendidik dalam bentuk teori dan perilaku sehingga anak didik termotivasi untuk melaksanakan nasihat dan himbauan guru. Bentuk pengajaran tersebut merupakan bentuk kinerja yang optimal dari seorang guru. Kinerja guru yang optimal merupakan modal dasar dalam pengembangan sumber daya manusia. Kinerja guru harus sesuai dengan standar yang telah disepakati, serta terlaksananya tugas dan tanggung jawab sesuai dengan kode etik guru. Namun, profesi pelayanan yang berhubungan dengan individu lain mudah terpicu konflik dan tekanan sehingga guru mudah mengalami kelelahan psikis maupun fisik Kondisi ini dapat menurunkan motivasi, kreativitas, kepercayaan diri dan ketrampilan emosi, tugas dan tanggung jawab guru sehingga kinerjanya tidak optimal.

\section{SIMPULAN}

Berdasarkan hasil penelitian, hubungan antara EQ dengan kinerja guru IPS adalah kuat positif, yaitu sebesar 0,634, dan arah positif menunjukkan bahwa semakin tinggi EQ maka semakin tinggi kinerja guru; (2) hubungan antara motivasi mengajar dengan kinerja guru adalah kuat positif, yaitu sebesar 0,641, dan arah positif menunjukkan bahwa semakin bagus motivasi mengajar guru IPS semakin tinggi kinerja guru; (3) hasil korelasi ( $r$ ) yang secara simultan (bersama-sama) antara EQ dan motivasi mengajar dengan kinerja guru diperoleh nilai sebesar 0,772 Dengan demikian kontribusi yang diberikan oleh keceerdasan emosional dan motivasi mengajar terhadap kinerja guru adalah koefisien determinasi sama dengan 0,596, artinya kinerja guru dipengaruhi EQ dan motivasi mengajar sebesar $59,6 \%$.

\section{REFERENSI}

Fitri, N. F., \& Adelya, B. (2017). Kematangan emosi remaja dalam pengentasan masalah. JPGI (Jurnal Penelitian Guru Indonesia), 2(2), 30-39. https://doi.org/10.29210/02225jpgi0005

Ghassani, N. S., \& Saifudin, A. (2020). Studi Metafora Konseptual pada Idiom Bahasa Jepang yang mengandung Bagian Tubuh dan Bermakna Emosi. Japanese Research on Linguistics, Literature, and Culture, 2(2), 161177. https://doi.org/10.33633/jr.v2i2.3990

Goleman, D. (2002). Kecerdasan Emosi untuk Mencapai Puncak Prestasi. Jakarta: Gramedia Pustaka.

Goleman, D. (2009). Kecerdasan Emosional: Mengapa EI Lebih Penting dari pada IQ. Jakarta: Gramedia Pustaka Utama.

Kristianto, D. (2012). Meningkatkan Motivasi Kerja Dengan Penghargaan Berbasis Kinerja Bagi Akuntan Publik. Jurnal Ekonomi dan Kewirausahaan, 10(2), 174-181.

Kurniasari, A. (2016). Gaya Pengasuhan Dan Kecerdasan Emosi Anak. Sosio Informa, 2(2), 185-202. https://doi.org/10.33007/inf.v2i2.269 
Nasryah, C. E., \& Rahman, A. A. (2019). Efektifitas Pendekatan Realistic Approach Dalam Meningkatkan Emotional Quotient (EQ) Siswa. Visipena, 10(2), 229-238. https://doi.org/10.46244/visipena.v10i2.503

Shofuroh, S., Arifin, B. S., \& Fahmi, I. (2012). Hubungan antara Kecerdasan Emosi dengan Kinerja Guru MTs Attaqwa Kota Tangerang. Psympathic: Jurnal Ilmiah Psikologi, 5(1), 500-510.https://doi.org/10.15575/psy.v5i1.2147

Siregar, S. (2014). Statistik Parametrik untuk Penelitian Kuantitatif. Jakarta: Bumi Aksara.

Sugiyono. (2013). Statistika Untuk Penelitian. Bandung: Alfabeta.

Supardi, U. (2013). Aplikasi Statistik dalam Penelitian. Jakarta: Adikita.

Tiro, M. A. (2002). Analisis Korelasi dan Regresi. Makassar: Universitas Negeri Makasar Press.

Tridhonanto, A.(2009). Melejitkan Kecerdasan Emosi (EQ) Buah hati: Panduan bagi Orang Tua untuk Melejitkan EQ (Kecerdasan Emosional). Jakarta: PTAlex Media Komputindo.

Yulika, R. (2019). Pengaruh kecerdasan emosi dan motivasi belajar terhadap prestasi belajar siswa di SMP Negeri 1 Sengkang. Inspiratif Pendidikan, 8(2), 252-270.https://doi.org/10.24252/ip.v8i2.7838 